\begin{tabular}{|c|c|c|}
\hline decartesian 9 & Jumal Matematika dan Aplikasi & \\
\hline & deOarcterian & \\
\hline$=-11 \mathrm{IIII}$ & $\begin{array}{c}\text { ISSN:2302-4224 } \\
\text { J o u r n a I h o m e p a g e: https://ejournal.unsrat.ac.id/index.php/decartesian }\end{array}$ & deCartesian \\
\hline
\end{tabular}

\title{
Penerapan Bilangan Kompleks untuk Menyelesaikan Soal-Soal Geometri Datar
}

\author{
Dwi Tristianto $^{1}$, Lilik Linawati ${ }^{1}$, Bambang Susanto ${ }^{1^{*}}$ \\ ${ }^{1}$ Program Studi Matematika-Fakultas Sains dan Matematika-UKSW, Jln. Diponegoro No. 52-60, Salatiga 50711, Indonesia \\ *Corresponding author: bambang.susanto@staff.uksw.edu
}

\begin{abstract}
A B S T RA K
Soal-soal geometri datar pada umumnya diselesaikan dengan definisi, aksioma dan teorema-teorema yang ada. Tetapi, soal-soal geometri datar tertentu dapat diselesaikan dengan konsep dan sifat bilangan kompleks, hal ini dikarenakan setiap titik pada bidang dapat diwakili dengan sebuah bilangan kompleks, demikian pula sebaliknya. Dalam makalah ini sifat-sifat bilangan kompleks diterapkan untuk menyelesaikan beberapa soal geometri datar. Untuk itu, dipilih beberapa soal geometri datar yang diselesaikan menggunakan pendekatan ini. Studi ini dilakukan dengan cara mempelajari dan mensurvei teori-teori yang berkaitan dengan bilangan kompleks dan aplikasinya pada geometri datar. Soal-soal yang dipilih merupakan soal yang diambil dari buku, catatan kuliah, karya ilmiah para ahli dibidangnya dan soal Olimpiade Matematika tingkat SMA. Soal-soal yang dikaji berkaitan dengan dua segmen garis sejajar (parallel), syarat tiga titik segaris (collinear), dua segmen garis saling tegak lurus (perpendicullar) dan syarat empat titik membentuk suatu segiempat talibusur (concyclic). Hasil dari penelitian ini adalah pembuktian dua sifat istimewa dari jajar genjang, penentuan hasil pencerminan suatu titik terhadap garis tertentu, penentuan letak titik tinggi dari suatu segitiga jika diketahui ketiga titik sudutnya dan dua tipe soal terakhir yang dibahas adalah soal OSAMO 2015 no. 2 dan OSN SMA 2009 tentang pembuktian dua segmen garis tegak lurus dan 4 titik tertentu membentuk suatu segiempat talibusur.
\end{abstract}

\section{PENDAHULUAN}

Soal-soal geometri datar pada umumnya dapat diselesaikan menggunakan definisi, aksioma dan teorema-teorema yang ada. Menurut Chandra [7] soalsoal geometri datar dapat juga diselesaikan menggunakan pendekatan geometri analitik. Pendekatan ini memang dapat membantu pada kondisi yang tepat, namun memiliki beberapa masalah. Menurut Chen [5] beberapa masalah itu diantaranya adalah: 1) untuk menentukan titik di bidang membutuhkan dua variabel, 2) persamaan yang terbentuk pada soal tentang geometri transformasi di bidang pada umumnya rumit sehingga sulit diselesaikan. Untungnya, masalah-masalah tersebut dapat ditangani dengan menggunakan bilangan kompleks.

Representasi bilangan kompleks sebagai titik-titik di bidang datar secara alami mengarah pada interaksi dua arah antara geometri dan bilangan. Dalam artikel penelitian Shastri [3] bilangan kompleks digunakan untuk penyelesaian soal-soal geometri di bidang yaitu:

\author{
INFO ARTIKEL \\ Diterima \\ : 18 Desember2017 \\ Diterima setelah revisi : 11 Januari 2018 \\ Tersedia online \\ : 31 Maret 2018

\section{Kata Kunci:} \\ Bilangan Kompleks, \\ Dua Segmen Garis Saling Tegak Lurus, \\ Dua Segmen Garis Sejajar, \\ Geometri Datar, \\ Syarat Empat Titik Membentuk Segiempat \\ Talibusur, \\ Syarat Tiga Titik Segaris.
}

syarat dua segmen garis sejajar 1), syarat tiga titik $A, B$, $C$ segaris 2), bagaimana menentukan titik tengah dari sebuah segmen garis 3), bagaimana menentukan diagonal-diagonal belah ketupat saling tegak lurus 4) dan syarat empat titik terletak pada satu lingkaran menggunakan cross-ratio. Sedangkan, pada artikel penelitian Shaw [1] penggunaan bilangan kompleks digunakan untuk penyelesaian soal tentang garis yang menghubungkan titik tengah sisi segitiga membagi segitiga itu menjadi 4 segitiga yang sama luasnya dan segitiga yang terbentuk adalah segitiga sama sisi 1) dan syarat cukup suatu segi empat merupakan jajar genjang adalah diagonal-diagonalnya saling memotong sama panjang 2). Beberapa aplikasi sederhana penerapan bilangan kompleks dapat memberikan solusi terbaik dalam menyelesaikan soal-soal geometri datar.

Tujuan penelitian ini, diterapkan konsep dan sifat bilangan kompleks untuk menyelesaikan permasalahan geometri datar. Untuk itu, diambil beberapa soal geometri datar yang akan diselesaikan. Soal-soal geometri yang diselesaikan berasal dari beberapa 
sumber seperti soal olimpiade matematika, catatan kuliah dan soal-soal dari karya para ahli.

\section{METODE PENELITIAN}

\subsection{Studi Literatur}

Studi ini dilakukan dengan cara mempelajari dan mensurvei teori-teori yang berkaitan dengan bilangan kompleks dan aplikasinya pada geometri datar.

\subsection{Langkah-Langkah Penelitian}

Langkah-langkah dalam menyusun makalah ini adalah sebagai berikut.

1. Studi awal tentang geometri datar selanjutnya bilangan kompleks.

2. Kemudian dipelajari fakta-fakta tentang sifat-sifat bilangan kompleks yang dapat dipakai untuk menyelesaikan soal-soal geometri datar.

3. Studi dilakukan dengan cara mempelajari buku, catatan kuliah dan karya ilmiah dengan topik terkait.

4. Kemudian dari studi tersebut semua bahan dirangkum sebagai satu kesatuan yang utuh.

\section{HASIL DAN PEMBAHASAN}

\subsection{Sifat-sifat Bilangan Kompleks}

Setiap bilangan kompleks mewakili sebuah titik di bidang demikian pula sebaliknya. Dalam pembahasan selanjutnya, notasi huruf besar digunakan untuk mewakili titik di bidang yang bersesuaian dengan bilangan kompleks dan huruf kecil untuk bilangan kompleks yang bersesuaian, misalkan $a$ adalah bilangan kompleks yang sesuai dengan titik $A$ di bidang. Secara khusus, titik pusat $O$ bersesuaian dengan bilangan kompleks nol [5].

Selanjutnya, akan dikemukakan beberapa sifat bilangan kompleks yang akan digunakan untuk pembahasan selanjutnya [4]:

1. Setiap bilangan kompleks $z$ dapat dikaitkan dengan vektor posisi $O Z$ di bidang kompleks dengan titik pangkal di $O$ dan titik ujung di $Z$. Dengan perkataan lain setiap bilangan kompleks dapat dipikirkan sebagai suatu vektor. Ini berarti penjumlahan dua bilangan kompleks itu sama persis dengan penjumlahan dua vektor dibidang.

2. Misalkan $z_{1}=x_{1}+i y_{1}$ dan $z_{2}=x_{2}+i y_{2}$ dua bilangan kompleks yang tidak segaris maupun tidak sejajar yang memiliki sifat $x z_{1}+y z_{2}=0$ dengan $x$ dan $y$ adalah dua bilangan real, maka pastilah $x=0$ dan $y=0$.

3. Syarat cukup dua garis tegak lurus $A B \perp C D$ adalah $\frac{d-c}{b-a}$ merupakan bilangan imajiner murni. Di sini $a$, $b, c$ dan $d$ adalah bilangan-bilangan kompleks yang bersesuaian dengan titik $A, B, C$ dan $D$.

4. Syarat cukup agar ketiga titik $A, B$, dan $C$ segaris adalah $\frac{c-a}{c-b}=\overline{\left(\frac{c-a}{c-b}\right)}$ merupakan bilangan imajiner murni. Di sini $a, b$, dan $c$ adalah bilangan-bilangan kompleks yang bersesuaian dengan titik $A, B$, dan $C$.
5. Syarat cukup titik $A, B, C$, dan $D$ membentuk segiempat talibusur adalah $\frac{c-a}{c-b}: \frac{d-a}{d-b}$ merupakan bilangan real. Di sini $a, b, c$ dan $d$ adalah bilanganbilangan kompleks yang bersesuaian dengan titik $A$, $B, C$ dan $D$.

6. Misalkan titik $A$ terletak diluar lingkaran satuan $S$, $A E$ dan $A F$ adalah dua garis singgung pada lingkaran tersebut yang ditarik dari titik $A$ sebagai mana terlihat pada Gambar. 1.

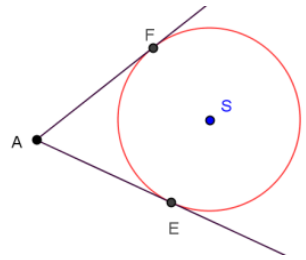

Gambar. 1. Sepasang garis singgung yang ditarik dari titik $A$

maka berlaku

$$
a=\frac{2}{e+f}
$$

Bukti fakta ini bisa dilihat di [4]

\subsection{Penerapan Bilangan Kompleks untuk Menyelesaikan Soal-Soal Geometri Datar}

Berikut ini disajikan soal-soal tentang geometri datar yang dapat diselesaikan dengan bilangan kompleks. Dipilih beberapa soal yang mewakili soal yang behubungan dengan kesejajaran, ketegaklurusan, kesegarisan dan segiempat talibusur. Soal-soal yang dipilih dianggap dalam penyelesaian dengan konsep dan sifat bilangan kompleks lebih mudah dibandingkan menggunakan hukum-hukum geometri Euclid.

Soal 1: Soal ini merupakan contoh soal yang diambil dalam artikel Geometric Aplication of Complex Number hal. 5 [1].

Misalkan $A B C D$ adalah jajar genjang dan $E, F, G, H$ adalah titik tengah dari masing-masing garis $A B, B C$, $C D, D A$. Tunjukkan bahwa $E G \| B C$ dan $F H \| C D$ dan $E F G H$ adalah jajar genjang.

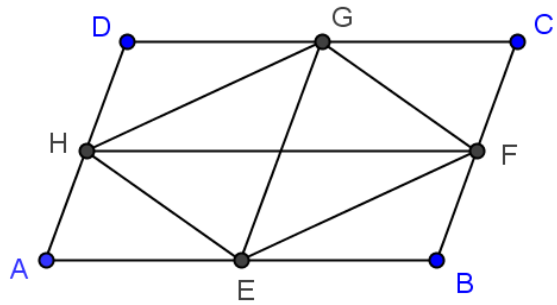

Gambar. 1. $A B C D$ adalah jajar genjang dengan $E, F, G, H$ adalah titik-titik tengah setiap sisinya.

Penyelesaian:

Perhatikan Gambar. 2. Misalkan $a, b, c$ dan $d$ bertututturut adalah bilangan kompleks yang bersesuaian dengan titik-titik $A, B, C$, dan $D$. Menggunakan sifat 1 , bilangan kompleks $\frac{1}{2}(a+b)$ mewakili titik tengah $\mathrm{E}$ sedangkan bilangan kompleks $\frac{1}{2}(c+d)$ mewakili titik tengah $G$. Jadi, $E G=\frac{1}{2}(c+d-a-b)$. 
Diketahui $A B C D$ adalah jajar genjang, maka $b-a=c-$ $d$ dan $d-a=c-b$. Sehingga

$E G=\frac{1}{2}(c+d-a-b)=\frac{1}{2}(d-a+c-b)=\frac{1}{2}(c-b+$ $c-b)=c-b=B C$.

Jadi, $E G$ dan $B C$ sejajar dan sama panjang. Selanjutnya, analog dengan cara di atas diperoleh

$H F=\frac{1}{2}(b+c-a-d)=\frac{1}{2}(b-a+c-d)=\frac{1}{2}(c-d+$ $c-d)=c-d=D C$.

Jadi, HF dan DC sejajar dan sama panjang.

Perhatikan segiempat $E F G H . E F=\frac{1}{2}(c-a)$ dan $G H=$ $\frac{1}{2}(c-a)$. Oleh karena itu, $E F$ dan $G H$ sejajar dan sama panjang, sehingga $E F G H$ adalah jajar genjang.

Q. E. D.

Soal 2: Soal ini merupakan soal no. 1.8 buku M. R. Spigel, [6] Complex Variables hal. 24. Buktikan bahwa kedua diagonal dalam jajar genjang saling potong memotong ditengah-tengah.

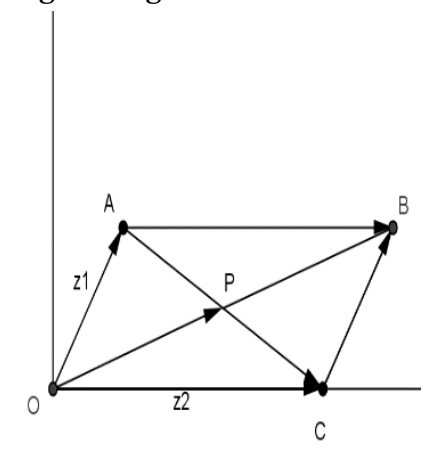

Gambar. 3. Kedua diagonal dalam jajar genjang saling potongmemotong ditengah-tengah.

Penyelesaian:

Perhatikan Gambar. 3. Misalkan $O A B C$ adalah jajar genjang dengan diagonal berpotongan di $P$. Misalkan pula $O A=z_{1}$ dan $O C=z_{2}$. Jadi, $O B=z_{1}+z_{2}$. Karena $z_{1}+A C=z_{2}, \quad A C=z_{2}-z_{1}, \quad$ maka $\quad A P=m\left(z_{2}-z_{1}\right)$ dengan $0 \leq m$. Dengan cara yang sama diperoleh $O P=$ $n\left(z_{1}+z_{2}\right)$ dengan $0 \leq n \leq 1$. Selanjutnya, akan ditunjukkan $m=n=1 / 2$. Tetapi $O A+A P=O P$ merupakan bilangan imajiner murni, sehingga $z_{1}+$ $m\left(z_{2}-z_{1}\right)=n\left(z_{1}+z_{2}\right) \quad$ atau $\quad(1-m-n) z_{1}+(m-$ $n) z_{2}=0$. Dengan demikian menurut sifat 2 diperoleh $(1-m-n)=0$ dan $m-n=0$. Ini berarti $m=1 / 2$, $n=1 / 2$. Jadi, terbukti $P$ adalah titik tengah dari diagonal tersebut.

Q. E. D.

Soal 3 [5]: Diberikan tiga titik $A, B$ dan $C$ yang tak segaris, seperti Gambar. 4. Misalkan $Z$ adalah pencerminan dari $C$ pada garis $A B$. Maka $Z$ dapat dinyatakan dalam bentuk sebagai berikut:

$$
z=\frac{a \bar{c}+b \bar{a}-a \bar{b}-b \bar{c}}{\bar{a}-\bar{b}}
$$

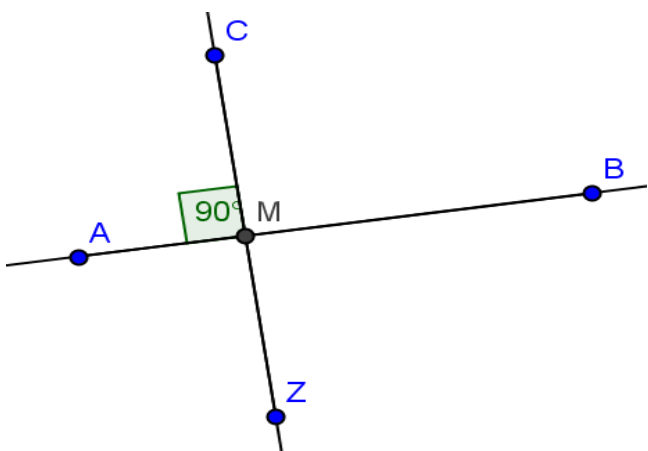

Gambar. 4. $Z$ adalah hasil pencerminan titik $C$ terhadap garis $A B$

Penyelesaian:

Perhatikan Gambar. 4. Misalkan $a, b, c$ dan $z$ bertututturut adalah bilangan kompleks yang bersesuaian dengan titik-titik $A, B, C$ dan $Z$._Misalkan pula $M$ adalah titik tengah dari $Z C$. Jadi,

$$
m=\frac{z+c}{2}
$$

Karena $Z$ adalah hasil pencerminan dari $C$ terhadap garis $A B$, maka $M$ pasti terletak pada garis $A B$. Sehingga menurut sifat 3 diperoleh

$$
\frac{m-b}{a-b}=\overline{\left(\frac{m-b}{a-b}\right)}
$$

Karena

$$
m=\frac{z+c}{2}
$$

maka

$$
\frac{z+c-2 b}{2(a-b)}=\frac{\bar{z}+\bar{c}-2 \bar{b}}{2(\bar{a}-\bar{b})}
$$

Demikian pula karena $Z C$ tegak lurus terhadap garis $A B$

$$
\frac{z-c}{a-b}=-\overline{\left(\frac{z-c}{a-b}\right)}=\frac{\bar{c}-\bar{z}}{\bar{a}-\bar{b}} .
$$

Selanjutnya, diperoleh

$$
\frac{z+c-2 b}{2(a-b)}=\frac{\bar{z}+\bar{c}-2 \bar{b}}{2(\bar{a}-\bar{b})}
$$

dan

$$
\frac{z-c}{a-b}=\frac{\bar{c}-\bar{z}}{\bar{a}-\bar{b}}
$$

Kedua persamaan (1) dan (2) dapat dipikirkan sebagai sistem persamaan dalam $\mathrm{z}$ dan $\bar{z}$. Sistem persamaan $\mathrm{Z}$ dan $\bar{z}$ dapat disajikan dalam bentuk sebagai berikut:

$P z+Q \bar{z}=R$

$U z+V \bar{z}$

$=W$

dengan

$P=\bar{a}-\bar{b}=U$

$Q=a-b$

$V=-(a-b)=b-a$

$R=a \bar{c}-b \bar{c}+\bar{a} c-\bar{b} c$

$W=a \bar{c}-b \bar{c}-2 a \bar{b}-\bar{a} c+2 \bar{a} b+\bar{b} c$

Apabila sistem persamaan (3) dan (4) diselesaikan untuk sistem persamaan untuk $z$ diperoleh

$z=\frac{\left|\begin{array}{cc}R & Q \\ W & V\end{array}\right|}{\left|\begin{array}{ll}P & Q \\ U & V\end{array}\right|}=\frac{R V-Q W}{P V-Q U}=\frac{a \bar{c}+b \bar{a}-a \bar{b}-b \bar{c}(2 b-2 a)}{(\bar{a}-\bar{b})(2 b-2 a)}$ 
$=\frac{a \bar{c}+b \bar{a}-a \bar{b}-b \bar{c}}{\bar{a}-\bar{b}}$

Q. E. D.

\section{Soal 4:}

Diketahui $a, b$, dan $c$ adalah bilangan kompleks yang terletak pada lingkaran satuan di bidang kompleks dan $h$ adalah bilangan kompleks $h=a+b+c$. Jika $A, B, C$ dan $H$ berturut turut adalah titik-titik pada bidang yang bersesuaian dengan bilangan kompleks $a, b, c$ dan $h$, maka buktikan bahwa titik $H$ merupakan titik potong dari garis tinggi segitiga $\mathrm{ABC}$ [5].

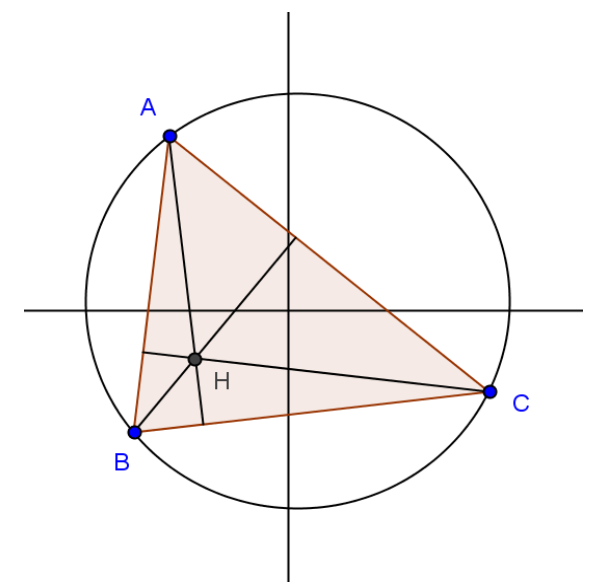

Gambar. 5. Titik $H$ merupakan titik potong garis tinggi segitiga $A B C$.

\section{Penyelesaian:}

Perhatikan Gambar. 5. Untuk membuktikan $H$ adalah titik tinggi segitiga $A B C$, ditunjukkan $H A \perp B C$. Jadi, menurut sifat 3 akan ditunjukkan bahwa bilangan $k=$ $\frac{h-a}{b-c}$ adalah bilangan imajiner murni.

Perhatikan bahwa

Dengan demikian

$$
k=\frac{(a+b+c)-a}{b-c}=\frac{b+c}{b-c} .
$$

$$
\begin{gathered}
\bar{k}=\overline{\left(\frac{b+c}{b-c}\right)}=\frac{\bar{b}+\bar{c}}{\bar{b}-\bar{c}}=\frac{1 / b+1 / c}{1 / b-1 / c}=\frac{c+b}{c-b}=-\frac{b+c}{b-c} \\
=-k .
\end{gathered}
$$

Oleh karena itu, terbukti $k$ adalah bilangan imajiner murni, sehingga $H A \perp B C$. Analog di atas $H C \perp A B$. Jadi, dapat disimpulkan bahwa $H B \perp C A$ dan $H C \perp A B$. Sehingga, $H$ adalah titik potong dari garis tinggi segitiga $A B C$, terbukti.

Q. E. D.

Soal 5: Soal berikut ini adalah soal no. 2 dari soal Olimpiade Matematika USAMO 2015 [5].

Pada Gambar. 6. Terlihat segiempat $A P B Q$ terletak pada lingkaran $\omega$ dengan $\angle P=\angle Q=90^{\circ}$ dan $A P=A Q<B P$. $X$ adalah sembarang titik pada segmen garis $P Q$ dan $\mathrm{S}$ adalah titik potong garis $A X$ dengan lingkaran $\omega$. Titik $T$ terletak pada busur $A Q B$ pada lingkaran $\omega$ sehingga $X T$ tegak lurus $A X$ dan $M$ adalah titik tengah segmen garis $S T$.

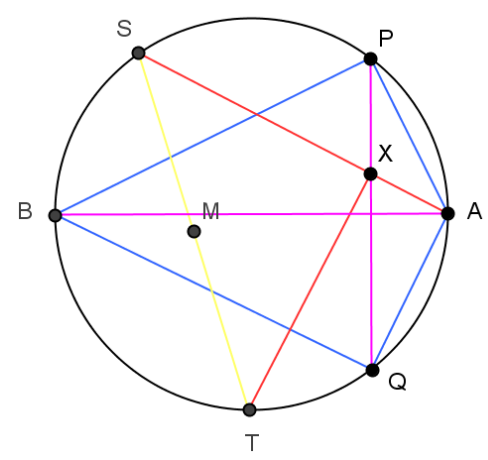

Gambar. 6. Ilustrasi latar belakang soal USAMO 2015 No. 2.

Jika $X$ bergerak sepanjang segmen garis $P Q$, maka tunjukkan bahwa $M$ bergerak sepanjang lingkaran.

Penyelesaian:

Perhatikan Gambar. 7.

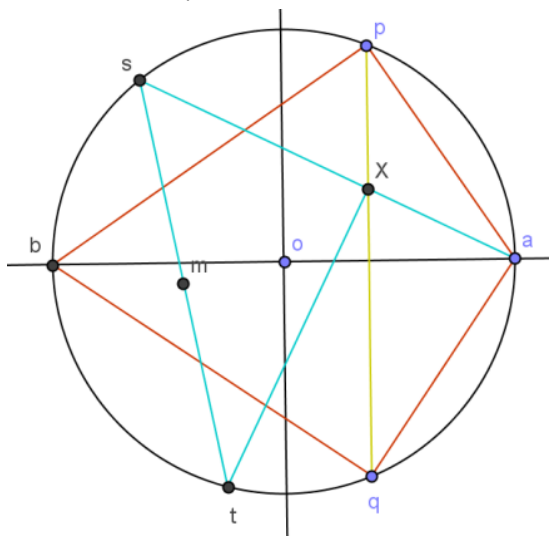

Gambar. 7. $a, b, m, \mathrm{o}, p, q, s, t$ dan $x$ bertutut-turut adalah bilangan kompleks yang bersesuaian dengan titik-titik $A, B, M, O, P, Q, \mathrm{~S}, T$ dan $X$.

Misalkan $a, b, s, t$ dan $x$ bertutut-turut adalah bilangan kompleks yang bersesuaian dengan titik-titik $A, B, S, T$ dan $X$. Tanpa mengurangi keumumannya dimisalkan $\omega$ merupakan lingkaran satuan dan $\mathrm{O}$ sebagai titik pusat lingkaran tersebut, maka $\angle P=\angle Q=90^{\circ}$.

Karena $A B$ merupakan diameter dari $\omega$, maka $a=1$ dan $b=-1$. Selanjutnya, perhatikan bahwa $A P B Q$ adalah layang-layang. Jadi, $P Q \perp A B$. Tetapi $A B$ berimpit dengan sumbu real, sehingga semua titik pada segmen garis $P Q$ tegak lurus terhadap sumbu real. Ini berarti semua titik pada segmen garis $P Q$ memiliki bagian real yang sama. Oleh karena itu, $\operatorname{Re}(x)$ konstan.

Karena $A, X$, dan $S$ segaris. Maka menurut sifat 4:

$$
\frac{x-t}{s-1}=\overline{\left(\frac{x-1}{s-1}\right)}=\frac{\bar{x}-1}{1 / s-1}
$$

Sedangkan $X T$ tegak lurus terhadap $A B$, maka menurut sifat 2:

$$
\frac{x-t}{s-1}=-\overline{\left(\frac{x-t}{s-1}\right)}=-\frac{\bar{x}-\frac{1}{t}}{1 / s-1}
$$

Apabila kedua persamaan (5) dan (6) diselesaikan untuk $x$ dan $\bar{x}$, akan diperoleh

dan 


$$
\bar{x}=\frac{1}{2}\left(1+\frac{1}{s}+\frac{1}{t}-\frac{s t}{s}\right)
$$

Perhatikan bahwa

$$
\begin{gathered}
\operatorname{Re}(x)=\frac{x+\bar{x}}{2} \\
=\frac{1}{4}\left(2+s+t+\frac{1}{s}+\frac{1}{t}-\frac{s}{t}-\frac{t}{s}\right) .
\end{gathered}
$$

Karena titik $Z$ terletak terletak pada lingkaran satuan $\omega$, maka $z=\frac{1}{2}$, sehingga

$$
\begin{aligned}
& |m-z|^{2}=\left|\frac{s+t-1}{2}\right|^{2} \\
& =\left(\frac{s+t-1}{2}\right)\left(\frac{s+t-1}{2}\right) \\
& =\frac{1}{4}(s+t-1)\left(\frac{1}{s}+\frac{1}{t}-1\right) \\
& =\frac{1}{4}\left(3-2-t-\frac{1}{s}-\frac{1}{t}+\frac{s}{t}+\frac{t}{s}\right) \\
& =\frac{5}{4}-\operatorname{Re}(x) .
\end{aligned}
$$

Terbukti bahwa $M$ terletak pada lingkaran dengan pusat $Z$ dan jari-jari $\sqrt{\frac{5}{4}-\operatorname{Re}(x)}$ Q. E. D.

Soal 6 : Soal ini merupakan salah satu soal seleksi tingkat kabupaten/kota OSN 2009 bidang matematika SMA [8]. Diberikan segitiga $A B C$ lancip. Lingkaran dalam segitiga $A B C$ dengan titik pusat $I$ menyinggung sisi-sisi $B C, C A$, dan $A B$ berurut-turut di $D, E$, dan $F$. Garis bagi sudut $A$ memotong $D E$ di K.

a) Buktikan bahwa $\mathrm{BK}$ tegak lurus garis bagi sudut $B A C$.

b) Buktikan bahwa CL tegak lurus garis bagi sudut $B A C$, dimana $L$ adalah titik potong garis bagi sudut $A$ dan garis $D F$.

c) Tunjukkan bahwa $A_{1} K M L$ adalah segiempat talibusur, jika $A A_{1}$ adalah garis tinggi dan $M$ titik tengah $B C$.

Ilustrasi soal di atas diperlihatkan pada Gambar. 8.

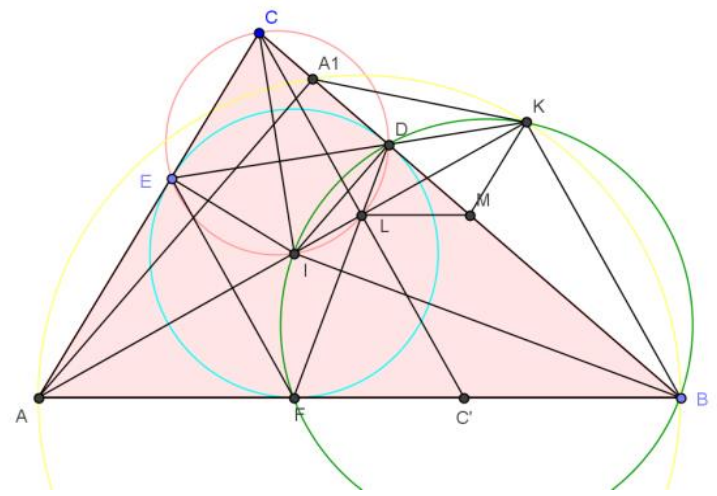

Gambar. 8. OSN SMA $2009 B K$ tegak lurus $A K, C L$ tegak lurus $A L$ dan $A_{l} K M L$ adalah segiempat talibusur.

\section{Penyelesaian:}

Tanpa mengurangi keumumannya lingkaran dalam segitiga $A B C$ dipikirkan sebagai lingkaran satuan dibidang kompleks dengan pusat koordinat di $I$ dan sumbu realnya berimpit dengan garis bagi sudut $A$ sebagaimana terlihat pada Gambar. 9.

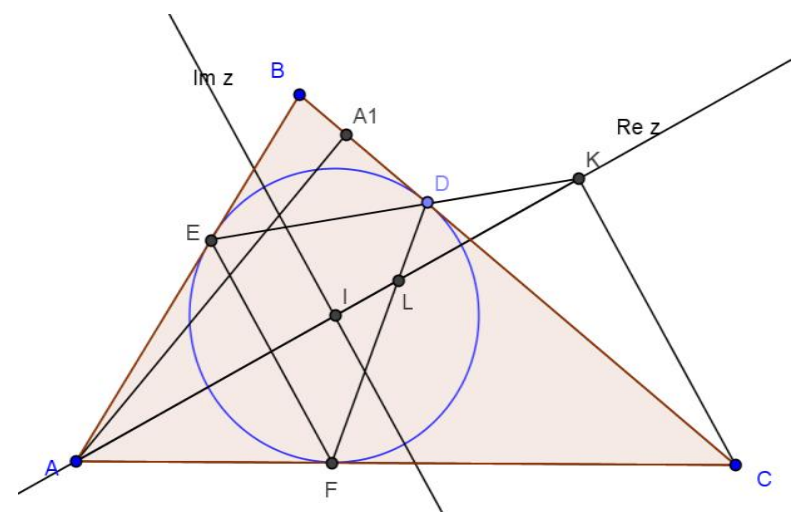

Gambar. 9. Titik $I$ merupakan pusat koordinat dan garis bagi $\angle \boldsymbol{A}$ merupakan sumbu real.

Jadi, persamaan garis bagi $\angle A$ adalah $z-\bar{z}=0$. Karena $E F$ tegak lurus $A I$ dan $E$ terletak pada lingkaran satuan, maka $f=\bar{e}=\frac{1}{e}$ atau ef $=1$.

Selanjutnya, menggunakan sifat 6 diperoleh

$$
a=\frac{2}{e+f}, b=\frac{2 d f}{d+f}, c=\frac{2 d e}{d+e} .
$$

Mengunakan sifat 2 diperoleh

$$
m=\frac{1}{2}(b+c)=\frac{d e}{d+e}+\frac{d f}{d+f}
$$

Misalkan $z$ sembarang titik yang terletak pada garis $D E$, maka $Z$ segaris dengan garis $D E$. Oleh karena itu berdasarkan sifat 4 persamaan garis $D E$ adalah

$$
\frac{z-d}{z-e}=\frac{\bar{z}-\bar{d}}{\bar{z}-\bar{e}}
$$

atau

$$
\frac{\bar{z}-1 / d}{\bar{z}-1 / e}=\frac{d \bar{z}-1}{d \bar{z}-\frac{d}{e}}
$$

Bentuk persamaan tersebut dapat disederhakan menjadi $(d-e) z+(d-e) e d \bar{z}=(d-e)(d+e)$ atau $z+d e \bar{z}=d+e$. Jadi, persamaan garis $D E$ adalah $z+$ $d e \bar{z}=d+e$. Dengan cara yang sama persamaan garis $D F$ adalah $z+d f \bar{z}=d+f$.

Misalkan $z$ sembarang titik pada $B C$ dan $I D \perp Z D$, maka berdasarkan sifat 3 diperoleh

$$
\frac{\overline{d-\imath}}{d-z}=-\frac{d-i}{d-z}
$$

Karena $I$ adalah titik pusat koordinat dan titik $D$ terletak pada lingkaran satuan, maka diperoleh $\frac{\bar{d}-0}{\bar{d}-\bar{z}}=-\frac{d-0}{z-d}$

atau

$$
\frac{\frac{1}{d}}{\frac{1}{d}-\bar{z}}=-\frac{d}{z-d}
$$

Jika persamaan (8) disederhanakan akan diperoleh $z+$ $d^{2} \bar{z}=d+d$. Jadi, persamaan garis $B C$ adalah $d^{2} \bar{z}=$ $2 d-z$.

Dengan cara serupa di atas, persamaan garis $A A_{1}$ diperoleh dari: 
atau

$$
\frac{z-a}{b-c}=-\frac{\bar{z}-\bar{a}}{\bar{b}-\bar{c}}
$$

$$
\frac{z-\frac{2}{e+f}}{\frac{2 d f}{d+f}-\frac{2 d e}{d+e}}=-\frac{\bar{z}-\frac{2}{e+f}}{\frac{2}{d+f}-\frac{2}{d+e}}
$$

Dengan menyederhanakan persamaan (9), maka persamaan garis akhir dapat ditulis dalam bentuk $z(e+f)-2=d^{2}(e+f) \bar{z}-2 d^{2}$.

Selanjutnya, dengan memotongkan garis $D E$ dan sumbu real $A I$ diperoleh titik $K$ yaitu

$$
k=\frac{d+e}{d e+1}
$$

Demikian pula dengan memotongkan garis $D F$ dan sumbu real $A I$ diperoleh titik $L$ yaitu

$$
l=\frac{d+f}{d f+1}
$$

Sementara itu dengan memotongkan garis $A A_{1}$ dan garis $B C$ diperoleh titik $A_{1}$ yaitu dengan mensubtitusikan persamaan garis $B C$ pada $A A_{1}$. Oleh karena itu, diperoleh persamaan garis $A_{1}$ yaitu $z(e+$ $f) 2=2 d(e+f)-2 d^{2}+2$. Sehingga, hasil akhir persamaan garis $A_{1}$ adalah

$$
z=\frac{d e+d f-d^{2}+1}{e+f}
$$

a) Untuk membuktikan $B K \perp K I$ cukup ditunjukkan $X=\frac{b-k}{i-k}$ bernilai imajiner.

$$
X=\frac{b-k}{i-k}=\frac{\frac{2 d f}{d+f}-\frac{d+e}{d e+1}}{0-\frac{d+e}{d e+1}}=\frac{e-d}{d+e}
$$

Sehingga

$$
\bar{X}=\frac{\bar{e}-\bar{d}}{\bar{d}+\bar{e}}=\frac{\frac{1}{e}-\frac{1}{d}}{\frac{1}{d}+\frac{1}{e}}=\frac{d-e}{d+e}=-X .
$$

Jadi, terbukti $X=\frac{b-k}{i-k}$ bernilai imajiner, sehingga terbukti pula $B K \perp K I$.

b) Untuk membuktikan bahwa $C L \perp L I$ dapat dilakukan dengan komputasi a).

c) Untuk membuktikan $A_{1} K M L$ adalah segiempat talibusur, perhatikan Gambar. 10.

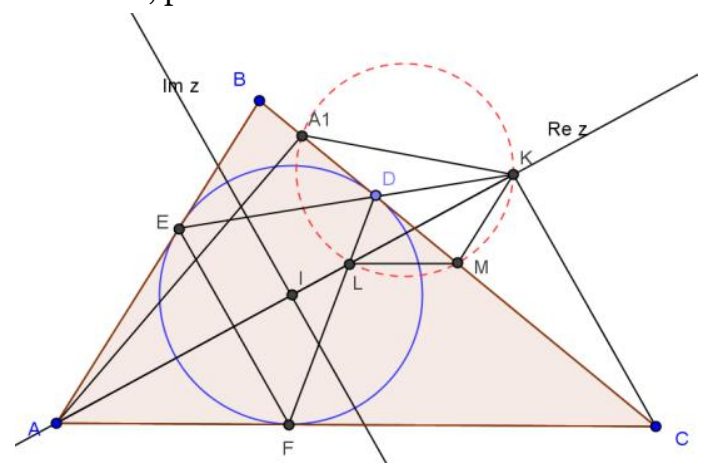

Gambar. 10. $A_{l} K M L$ adalah segiempat talibusur.

Cukup ditunjukkan

$$
Y=\frac{a_{1}-k}{m-k}: \frac{a_{1}-l}{m-l}
$$

bernilai real. Perhatikan bahwa

$$
\frac{a_{1}-k}{m-k}=\frac{\frac{d e+d f-d^{2}+1}{e+f}-\frac{d+e}{d e+1}}{\frac{d e}{d+e}+\frac{d f}{d+f}-\frac{d+e}{d e+1}}=\frac{e^{2}-d^{2}}{e^{2}+1}
$$

dan

$$
\frac{a_{1}-l}{m-l}=\frac{\frac{d e+d f-d^{2}+1}{e+f}-\frac{d+f}{d f+1}}{\frac{d e}{d+e}+\frac{d f}{d+f}-\frac{d+f}{d f+1}}=\frac{1-d^{2} e^{2}}{e^{2}+1}
$$

Sehingga

$$
Y=\frac{e^{2}-d^{2}}{e^{2}+1}: \frac{1-d^{2} e^{2}}{e^{2}+1}=\frac{e^{2}-d^{2}}{1-d^{2} e^{2}}
$$

Akibatnya

$$
\bar{Y}=\frac{\frac{1}{e^{2}}-\frac{1}{d^{2}}}{1-\frac{1}{d^{2} e^{2}}}=\frac{d^{2}-e^{2}}{d^{2} e^{2}-1}=Y .
$$

Jadi, terbukti bahwa $Y$ adalah real, maka terbukti $A_{1} K M L$ adalah segi empat tali busur Q. E. D.

\section{KESIMPULAN}

Dalam makalah ini telah dibahas bagaimana membuktikan dan menyelesaikan beberapa soal geometri datar yang dapat diselesaikan dengan bantuan bilangan kompleks. Dengan memasukkan rumus sifatsifat bilangan kompleks yang terkait ke soal geometri datar dapat diselesaikan. Tipe-tipe soal yang diselesaikan adalah pembuktian dua sifat istimewa dari jajar genjang, penentuan hasil pencerminan suatu titik terhadap garis tertentu dan penentuan letak titik tinggi dari suatu segitiga jika diketahui ketiga titik sudutnya. Dua tipe soal terakhir yang dibahas adalah soal OSAMO 2015 no.2 dan OSN 2009 tentang pembuktian dua segmen garis tegak lurus dan 4 titik tertentu membentuk suatu segiempat talibusur. Pembaca disarankan menggunakan bilangan kompleks jika menemui kesulitan dalam usaha menyelesaikan soalsoal geometri yang berkaitan dengan kesejajaran (parallel), ketegaklurusan dua segmen garis (perpendicullar) dan soal yang melibatkan collinier (segaris) dan concyclic (segiempat talibusur). Pada makalah ini tidak membandingkan pendekatan bilangan kompleks dengan metode klasik melainkan hanya sebagai pelengkap dari metode pembuktian yang ada.

\section{REFERENSI}

[1] A. A. Shaw, "Geometric Aplication Of Complex Numbers," School Science And Mathematic, vol. 31, 6, pp. 754-761, June 1931.

[2] A. Jobbings, (2009, March 17). Geometry by numbers. Arbelos [Online]. Avaliable: http://www.arbelos.co.uk/Papers/Geometrynumbers.pdf.

[3] A. R. Shastri, "Complex Numbers and Plane Geometry," Indian Academy of Sciences 2008," vol. 13, 1, pp. 35-53, 10 Feb, 2008.

[4] E. Chen, (2015, Aug 29). Bashing Geometry with Complex Numbers [Online]. Available: http://studylib.net/doc/18172223/bashing- 
geometry-with-complex-numbers-1-the-complexplane.

[5] H. Chen, (2016, April). Geometry in the Complex Plane [Online]. Avaliable: https://uncmathcontest.files.wordpress.com/201 6/o4/complexbash.pdf. [23 Juli 2017]

[6] M. R. Spigel, Complex Variables (2ed), Schaum's Series, Mc Graw-Hill, 2009.

[7] T. D. Chandra, "Penerapan Geometri Analitik Dalam Penyelesaian Soal-Soal Geometri," Jurnal Pembelajaran Matematika, Tahun 2, No. 1, Jan. 2013.

[8] T. Widodo, (2016, Jan 12). Geometri From OSN. Tuturwidodo. Avaliable: tuturwidodo.com/ebook-geometri-from-osn/. [15 juli 2017]

\section{Lampiran A. Sifat Bilangan Kompleks}

Pada bagian ini akan diberikan sifat bilangan kompleks yang digunakan dan dituliskan dalam penelitian ini. Misalkan $a, b, c$, dan $d$ adalah bilanganbilangan kompleks yang bersesuaian dengan titik $A, B$, $C$ dan $D$.

1. Syarat cukup dua garis tegak lurus $A B \perp C D$ adalah $\frac{d-c}{b-a}$ merupakan bilangan imajiner murni.

2. Syarat cukup agar ketiga titik $A, B$, dan $C$ segaris adalah $\frac{c-a}{c-b}=\overline{\left(\frac{c-a}{c-b}\right)}$ merupakan bilangan imajiner murni.

3. Syarat cukup titik $A, B, C$, dan $D$ membentuk segiempat talibusur adalah $\frac{c-a}{c-b}: \frac{d-a}{d-b}$ merupakan bilangan real.

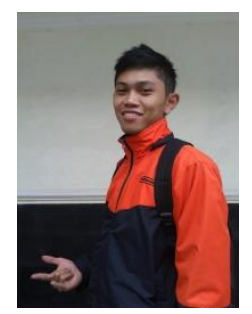

Dwi Tristianto lahir dan tinggal di Kauman Kidul, Kota Salatiga.

Dia masih menempuh pendidikan tinggi di Program Studi Matematika, Fakultas Sains dan Matematika, Universitas Kristen Satya Wacana (UKSW) Salatiga. Tahun 2018 adalah tahun terakhir ia menempuh studi. Makalah ini merupakan hasil penelitian skripsinya yang dipublikasikan.

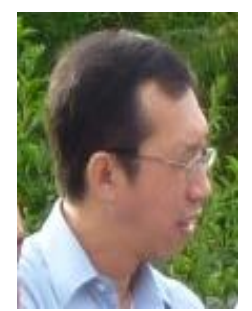

Bambang Susanto lahir di Ambarawa, Jawa Tengah, pada tanggal 12 Juli 1963 Pada tahun 1992, gelar Magister Sains (M.Si) diperoleh dari Program Pascasarjana Magister Matematika Institut Teknologi Bandung (ITB) dan menyelesaikan program $\mathrm{S}_{3}$ pada tahun 2005 di lembaga yang sama. Sejak tahun 1988 sampai saat ini, ia menjadi Pengajar Tetap di UKSW. Beberapa mata kualiah yang diampu adalah Fungsi Kompleks, Teknik Peramalan dan Analisis Data Multivariat. Salah satu makalah yang ditulisnya besama dengan mahasiswa dan pembimbing utamanya adalah Model Volatilitas Garch(1,1) Dengan Error Student-T Untuk Kurs EUR Dan JPY Terhadap IDR yang dipublikasikan pada Jurnal MIPA, Fakultas MIPA Universitas Negeri Semarang.

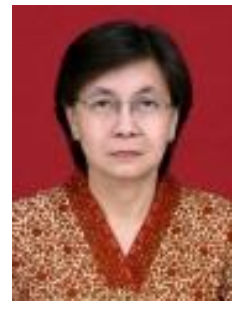

Lilik Linawati lahir di Blitar 14 agustus 1959. Tahun 1984 lulus S1 Pendidikan Matematika IKIP Sanata Dharma Yogyakarta dan tahun 2003 lulus S2 Ilmu Komputer Universitas Gajah Mada Yogyakarta. Menjadi tenaga akademik tetap di UKSW sejak tahun 1985 pada Pusat Pelayanan Komputer dan pada 1998 bergabung ke Fakultas Sains Matematika Program Studi Matematika. Beberapa matakuliah yang diampu adalah Program Linear, Riset Operasi, Pemodelan Fuzzy, Geometri Euclide, Geometri Analit. Fokus penelitian pada bidang Optimasi dan pembelajaran Matematika. 